\title{
Effect on Quality of Cucumber (Pant Shankar Khira-1) Hybrid Seed Production under Protected Conditions
}

\author{
Mukulkumar, H.S. Sirohi, Balraj Singh, B.S. Tomar and Mohit Kumar* \\ Department of Horticulture, CCR (P.G), College, Muzaffarnagar (UP), India \\ *Corresponding author
}

\begin{abstract}
A B S T R A C T
Keywords

Seed length, Seed

width, 100 seed

weight, Germination

$\%$, Vigor indices, EC

and insect proof net

house

Article Info

Accepted:

04 December 2017

Available Online:

10 January 2018

The present investigation was carried out under insect proof net house and open field during Kharif season of 2013 and 2014for Cucumber (Pant sankar khira-1) hybrid seed production. Seed length was significantly higher under insect proof net hose (11.32) comparison to open field condition (10.36). Seed width $(\mathrm{mm})$, seed coat weight $(\mathrm{mm})$, cotyledon weight $(\mathrm{g})$ and 100 seeds weight $(\mathrm{g})$ were also significantly higher under insect proof net house $(4.11,0.13,0.13$ and 3.48 respectively) than open field condition (3.39, $0.10,0.14$ and 2.59 respectively). The germination percentage, seedling length (plate 3 ), vigour index I and II were significantly higher under insect proof net house (87.21, $31.43 \mathrm{~cm}, 2825.54$ and 11.08 respectively) but significantly lower in open field condition $(82.02,26.38 \mathrm{~cm}, 2224.83$ and 7.62 respectively). Electrical conductivity was lower under insect proof net house (11.22) but higher in open field condition (12.03).

\section{Introduction}

Cucumber belong to the Cucurbitaceae family and is knows as scientifically as Cucumis sativus. It is important of summer vegetable crop cultivated throughout India. Cucumber plant has climbing and trailing habit and tender cucumber can be eaten raw or with salt in salad. Cucumber contains unique antioxidants in moderate ratios such as Bcarotene and $\alpha$-carotene, vitamin-c, vitaminA, Zeaxanthin, and lutein. Cucumber crop is extensively grown during kharif and summer seasons in all parts of India, but seed production especially hybrid seed production

requires vigorous growth, higher number of female flower in seed parent and higher fruit set for better fruit maturation and development attributes. Hybrid seed production under north Indian condition cannot be organized successfully in open field condition because of high incidence of viral diseases and white fly attack in kharif season. The seed crop grown under insect-proof net house overcomes the threats of insect vectors, viral diseases and unfavorable climatic conditions (Flemin et al., 2012). Present investigation was planned to effect of insect-proof net house on seed quality of cucumber (pant sankar khira-1) during hybrid seed production.

Materials and Methods
\end{abstract}


The present investigation was carried out to during Kharif season of 2013 and kharif season of 2014 at Centre for Protected Cultivation Technology, Indian Agricultural Research Institute, New Delhi and CCR (PG) College, Muzaffarnagar (UP) under two different growing environments i.e. insect proof net house and open field condition. The hybrid selected for the experiment was Pant Shankar Khira-1, the fruits are long (about 20 $\mathrm{cm}$ ), cylindrical and green with light strips. Insect proof net house was fabricated by using 40 mesh UV stabilized nylon net, white in colour with double door facility, with $2 \mathrm{~m}^{2}$ waiting area and having length $60 \mathrm{~m}$, width $6 \mathrm{~m}$, height $2 \mathrm{~m}$ was used for raising hybrid seed crop. Thirty plants were randomly selected in both the growing conditions for recording the observations viz., Seed length, seed width, 100 seed weight, germination \%, vigor indices, electrical conductivity.

Similarly the laboratory tests were carried out at post graduate laboratory, Division of Seed Science and Technology, IARI, New Delhi which includes germination (\%) (ISTA, 2012), seedling length $(\mathrm{cm})$, vigour index-I and II (Abdulbaki and Anderson, 1973) and electrical conductivity (Dadlani and Agarwal, 1987). The quantitative data generated were analyzed statistically by using SAS 9.2 for testing the heterogeneity of means adopting the independent ' $t$-test' procedures.

\section{Results and Discussion}

The data presented in the table 1, 2 and Figure 1,2 showed significantly higher values for Seed length $(\mathrm{mm})$, Seed width $(\mathrm{mm})$, seed coat weight, Cotyledon weight (g) and 100 seed weight were significantly higher in insect proof net house $(11.32,4.11,0.13,0.13$ and 3.48 respectively) but significantly lower in open condition $(10.36,3.39,0.10,0.14$ and 2.59 respectively). The data presented in the table 2 and Figure 3, 4, 5 showed that germination percentage, seedling length, vigour index I and II were significantly higher in insect proof net house $(87.21,31.43 \mathrm{~cm}$, 2825.54 and 11.08 respectively) but significantly lower in open condition (82.02, $26.38 \mathrm{~cm}, 2224.83$ and 7.62 respectively). Among the growing environments the insectproof net house showed lowest electrical conductivity (11.22) and open field conditions (12.03). The less electrical conductivity under insect-proof net house was due to welldeveloped seed coat which releases less seed lechate as compare to open field grown seeds released more seed lechate. The similar results were obtained by Flemine Xavier (2010) in pumpkin hybrid seed production, Gograj Singh Jat (2016) in bitter gourd hybrid seed production and KunjBhihari (2012) in summer squash hybrid seed production under insect proof net house and GirishKaddi (2014) in cucumber hybrid seed production under different growing conditions i.e. poly house, insect proof net house and open field.

Table.1 Effect of insect proof net house on Seed length, Seed width, Cotyledon weight, Seed coat weight and 100-seed weight, of cucumber (Pant Shankar Khira-1) during hybrid seed production in kharif season of 2013 and kharif season of 2014

\begin{tabular}{|l|c|c|c|c|c|}
\hline $\begin{array}{l}\text { Growth } \\
\text { condition }\end{array}$ & $\begin{array}{l}\text { Seed length } \\
(\mathbf{m m})\end{array}$ & $\begin{array}{l}\text { Seed width } \\
(\mathbf{m m})\end{array}$ & $\begin{array}{l}\text { Cotyledon } \\
\text { weight }(\mathbf{g})\end{array}$ & $\begin{array}{l}\text { Seed coat } \\
\text { weight }(\mathbf{g})\end{array}$ & $\begin{array}{l}\text { 100 seed } \\
\text { weight }(\mathbf{g})\end{array}$ \\
\hline Net House & 11.32 & 4.11 & 0.13 & 0.13 & 3.48 \\
\hline Open & 10.36 & 3.39 & 0.14 & 0.10 & 2.59 \\
\hline CD at 5\% & 1.58 & 0.52 & 0.012 & 0.004 & 1.05 \\
\hline SE (d) & 0.69 & 0.29 & 0.004 & 0.002 & 0.43 \\
\hline
\end{tabular}


Table.2 Effect of insect proof net house onGermination (\%), Seedling length, Vigour index I, Vigour index II and Electrical conductivity of cucumber (Pant Shankar Khira-1) during hybrid seed production in kharif season of 2013 and kharif season of 2014

\begin{tabular}{|l|c|c|c|c|c|}
\hline $\begin{array}{c}\text { Growth } \\
\text { condition }\end{array}$ & $\begin{array}{c}\text { Germination } \\
(\%)\end{array}$ & $\begin{array}{l}\text { Seedling } \\
\text { length }(\mathbf{c m})\end{array}$ & $\begin{array}{l}\text { Vigour } \\
\text { index I }\end{array}$ & $\begin{array}{c}\text { Vigour index } \\
\text { II }\end{array}$ & $\begin{array}{c}\text { Electrical } \\
\text { conductivity } \\
\text { (mmho/g/cm) }\end{array}$ \\
\hline Net House & 87.21 & 31.43 & 2825.54 & 11.08 & 11.22 \\
\hline Open & 82.02 & 26.38 & 2224.83 & 7.62 & 12.03 \\
\hline CD at 5\% & 4.54 & 3.41 & 34.69 & 1.46 & 1.40 \\
\hline SE (d) & 2.06 & 1.55 & 15.75 & 0.66 & 0.60 \\
\hline
\end{tabular}

Fig. 1: Effect of insect-proof net house on 100-seed weight $(\mathrm{g})$, seed length $(\mathrm{mm})$

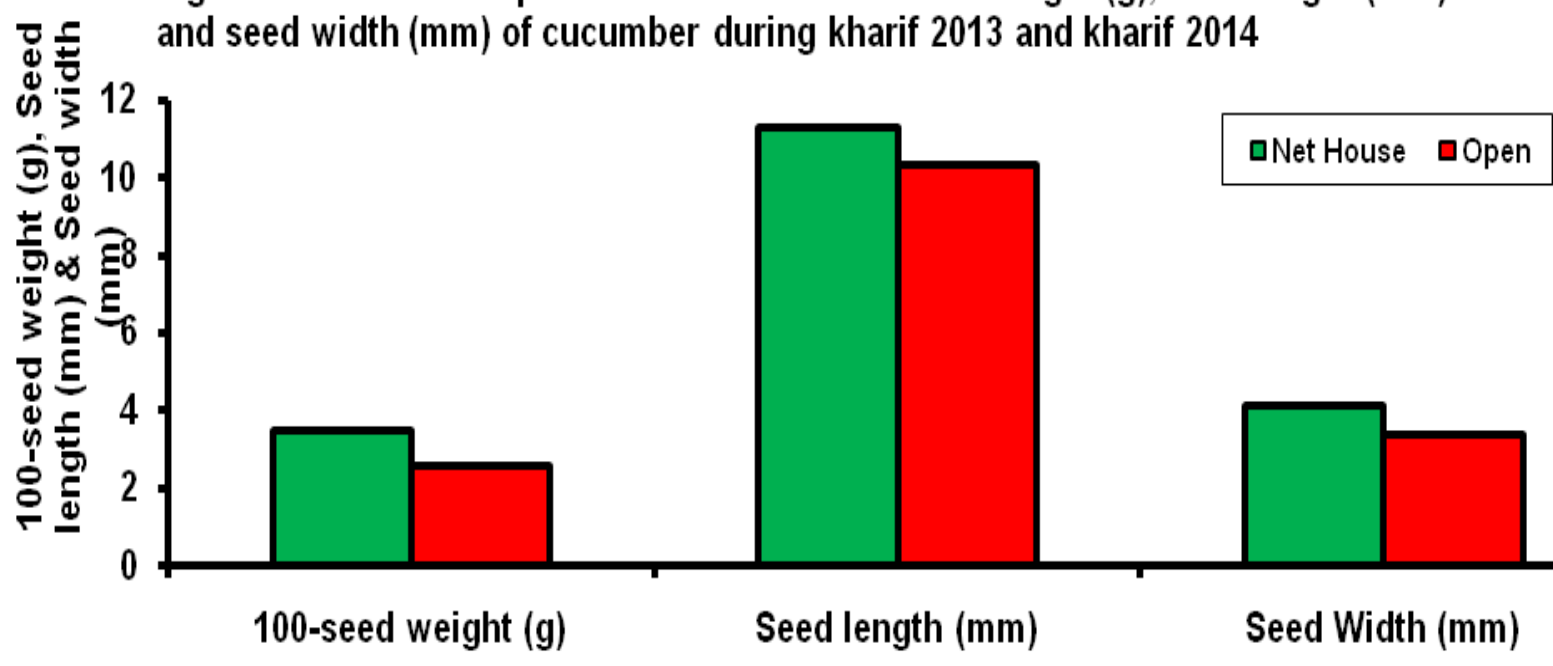

Fig. 2: Effect of insect-proof net house on cotyledon weight $(\mathrm{g})$ and seed coat weight $(\mathrm{g})$ of cucumber during kharif 2013 and 2014

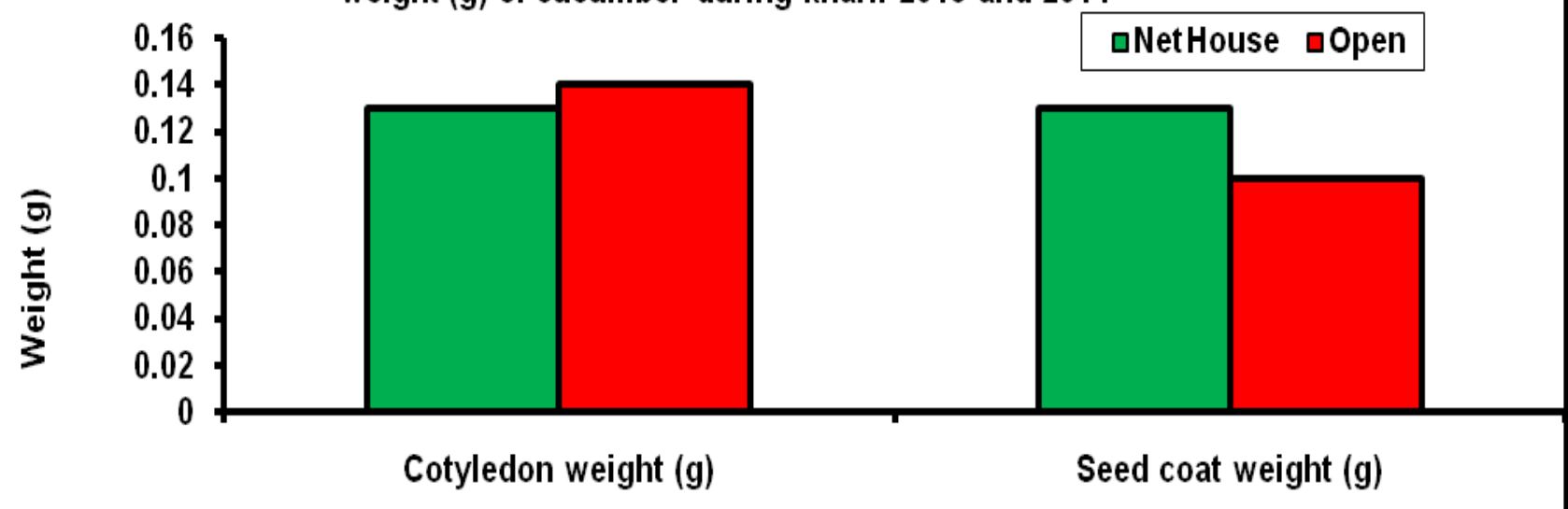


Fig. 3: Effect of insect-proof net house on germination (\%) and seedling length $(\mathrm{cm})$ of cucumber during kharif 2013 and kharif 2014
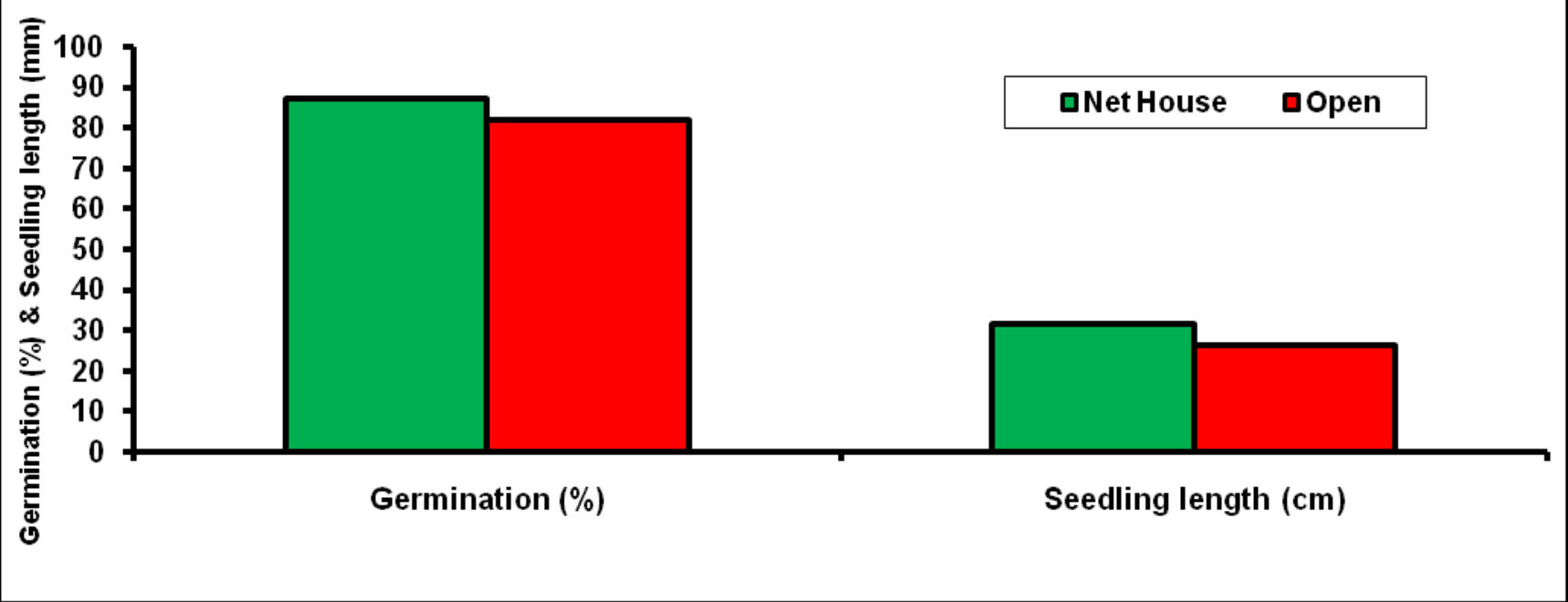

Fig 4: Effect of insect-proof net house on seed vigour index I of cucumber during kharif 2013 and kharif 2014

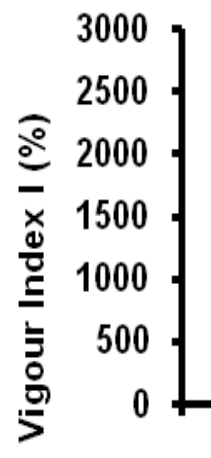

kharif 2013 andkharif 2014

aNet House aOpen

Seed vigour index I

Fig. 5: Effect of growing conditions on seed vigour index II of cucumber during kharif 2013 and 2014

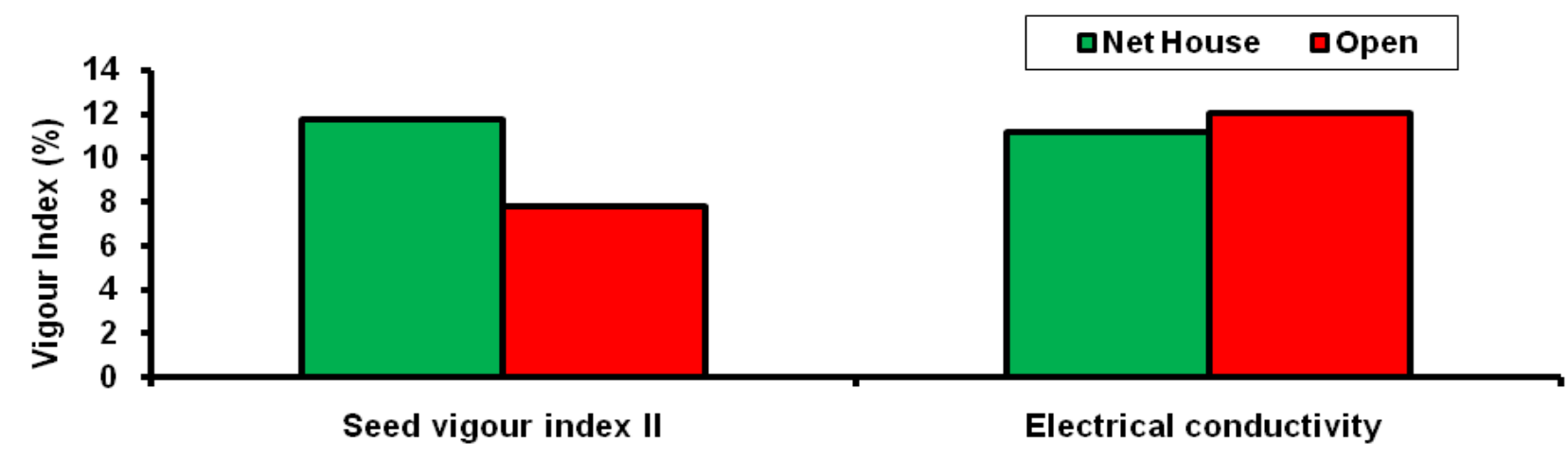


As per the result of this experiment it could be concluded that for attaining seed quality, seed length, seed width, seed coat weight, 100 seed weight, germination $\%$, seed vigour indux-I, seed vigour indux-II high and electrical conductivity low. The hybrid seed production of cucumber Pant Shankar Khira-1 should be undertaken in insect proof net house in kharif condition. The growing of seed crop under insect proof net house fetches higher net returns as compared to open field.

\section{Acknowledgements}

The authors are thankful to the Centre for Protected Cultivation Technology, Indian Agricultural Research Institute, New Delhi; CCR (PG) College, Muzaffarnagar (UP) and post graduate laboratory, Division of Seed Science \& Technology, IARI, New Delhi for providing the required research facilities.

\section{References}

Bihari, K., Singh, B., Tomar, B. S. and Kumar, M. 2012. Effect of growing conditions, time of pollination and fruit retention in hybrid seed production of summer squash (Cucurbita pepo). Journal of Seed Research Vol. 40(1): 21-29.

Flemine, X. 2010. Studies on hybrid seed production in pumpkin under insect proof net house and open field conditions. M.Sc. Thesis, Indian Agriculture Research Institute, New Delhi-110012.

Jat, G. S., Singh, B., Tomar, B. S., Singh, J., Ram, H., and Kumar, M. 2016. Seed yield and quality as influenced by growing conditions in hybrid seed production of bitter gourd (Momordica charantia L.) cv. Pusa hybrid-1. Journal of applied and natural science 8(4): 2111-2115.

Kaddi, G., Tomar, B. S., Singh, B. and Kumar, S. 2014. Effect of growing conditions on seed yield and quality of cucumber (Cucumis sativus) hybrid. Indian Journal of Agricultural Sciences84 (5):624-7.

\section{How to cite this article:}

Mukulkumar, H. S. Sirohi, Balraj Singh, B. S. Tomar and Mohit Kumar. 2018. Effect on Quality of Cucumber (Pant Shankar Khira-1) Hybrid Seed Production under Protected Conditions. Int.J.Curr.Microbiol.App.Sci. 7(01): 26-30.

doi: https://doi.org/10.20546/ijcmas.2018.701.004 